JOURNAL OF MECHANICAL ENGINEERING, MANUFACTURES, MATERIALS AND ENERGY

Doi: $10.31289 /$ jmemme.v5i2.5181

Available online http://ojs.uma.ac.id/index.php/jmemme

\title{
Studi Numerik Centrifugal Fan Tipe Impeller Backward dengan Variasi Putaran Fan
}

\section{Numerical Study of Impeller Backward Type Centrifugal Fan with Fan Rotation Variation}

\author{
Lohdy Diana1)*, Achmad Setiyawan2), Achmad Bahrul Ulum³), Arrad Ghani Safitra4), \\ Muhammad Nabiel 5 ) \\ 1,2,3,4,5 Politeknik Elektronika Negeri Surabaya
}

Diterima: 02-05-2021 ; Disetujui: 29-07-2021 ; Diterbitkan: 30-12-2021

*Corresponding author: E-mail: lohdydiana@pens.ac.id

\begin{abstract}
Abstrak
Primary air fan berfungsi sebagai penghasil udara primer yang digunakan sebagai udara pengangkut serbuk batubara dari pulverizer menuju burner untuk dibakar pada ruang bakar boiler. Penelitian ini bertujuan untuk mengetahui pengaruh variasi putaran fan terhadap karakteristik aliran fluida berupa distribusi tekanan total, tekanan dinamis, tekanan statis, distribusi kecepatan dan efisiensi optimal pada centrifugal fan. Penelitian ini dilakukan secara numerik dengan mensimulasikan centrifugal fan tipe impeller backward dalam model dua dimensi menggunakan software komputasi fluida dengan metode multiple reference frames dengan variasi putaran. Berdasarkan visualisasi distribusi tekanan dan distribusi kecepatan dapat disimpulkan terjadi fenomena volute hal tersebut ditandai dengan semakin besar luasan di volute maka semakin besar nilai pressure total. Berdasarkan visualisasi distribusi kecepatan outlet posisi -0,8531m sampai -1,01301m hasil kecepatan bernilai mendekati nilai 0 $\mathrm{m} / \mathrm{s}^{2}$ hal tersebut menunjukkan bahwa kecepatan minimum di area tersebut akibat profil volute yaitu radius volute tongue terjadi tabrakan aliran dan mengakibatkan kecepatan di daerah tersebut mengalami penurununan kecepatan hingga $\mathrm{V}=0$. Berdasarkan hasil simulasi yang dilakukan didapatkan bahwa semakin besar nilai putaran fan belum tentu nilai efisiensi juga akan semakin besar hal itu terverifikasi dengan data operasi aktual centrifugal fan dengan nilai range putaran minimum $1194 \mathrm{rpm}$ sampai maksimum $1468 \mathrm{rpm}$.
\end{abstract}

Kata Kunci: Centrifugal fan; Primary air fan; Efisiensi; rpm.

\begin{abstract}
The primary air fan functions as a primary air producer which is used as air to transport coal powder from the pulverizer to the burner to be burned in the boiler furnace. This study aims to obtain the effect of the rotation variation of fan to fluid flow characteristics such as the distribution of total pressure, the dynamic pressure, the pressure static contours, velocity distribution, and the fan optimal efficiency. This study was numerical study with simulated a backward impeller type centrifugal fan in a two-dimension model using Fluid Computational software with the multiple reference frame method with the variation of fan rotation. Based on the visualization of the pressure contour and velocity distribution, it could be concluded that there was a volute phenomenon, this was indicated that the greater the volume area in the volute is the greater the total pressure value too. Based on the visualization of the outlet velocity distribution at the position of $-0,8531 \mathrm{~m}$ to $-1,01301 \mathrm{~m}$, it was found that the velocity is close to the value of $0 \mathrm{~m} / \mathrm{s} 2$. It showed that the minimum velocity in the area due to the volute tongue radius occurs a flow collision and it impacted the velocity in the area decreased up to $V=0$. From the simulation results, it was found that the greater the fan rotation value was the greater the efficiency value too. It would be verified by the actual operating data of the centrifugal fan with a minimum rotation range value of $1194 \mathrm{rpm}$ to a maximum of $1468 \mathrm{rpm}$.
\end{abstract}

Key words: Centrifugal fan; Primary air fan; Efficiency; rpm.

How to Cite: Diana, L. 2021, Studi Numerik Centrifugal Fan Tipe Impeller Backward dengan Variasi Putaran Fan, JMEMME (Journal of Mechanical Engineering, Manufactures, Materials and Energy), Vol 5 (2): 168-178. 


\section{PENDAHULUAN}

Pembangkit listrik berbahan bakar batubara membutuhkan udara untuk proses produksi listrik. Masukkan udara dapat dibagi menjadi dua, yaitu primary air fan untuk menghasilkan udara primer dan secondary air fan untuk menghasilkan udara sekunder. Kedua fan tersebut merupakan komponen penting pada pembangkit listrik tenaga uap berbahan bakar batubara. Pada Pembangkit Listrik Tenaga Uap (PLTU) ada beberapa fan yang digunakan, seperti primary air fan, secondary air fan, dan induced draft fan. Dalam penelitian ini akan membahas primary air fan. Udara primer yang dihasilkan oleh Primary air fan yang digunakan sebagai udara pengangkut serbuk batubara dari pulverizer menuju burner untuk dibakar di furnace boiler sekaligus sebagai pengering batubara.

Beberapa penelitian dilakukan untuk mengetahui performa fan, penelitian tersebut antara lain: Primary air fan menggunakan fan jenis centrifugal dengan tipe bentuk blade backward-curved [1]. Secara sederhana, fan atau kipas merupakan alat yang yang memiliki fungsi memindahkan sejumlah udara atau gas pada tekanan tertentu dan (ASME) mendefinisikan perbedaan fan, blower, dan kompresor menggunakan rasio spesifik atau rasio tekanan keluar (discharge) terhadap tekanan hisap (suction) [2]. Klafisikasi Fan memiliki rasio spesifik 1,11 dan Blower memiliki rasio spesifik lebih dari 1,11 dan kurang dari 1,20 sedangkan kompresor memiliki rasio spesifik lebih dari 1,20 [3]. Pada kasus konsumsi daya mesin, mesin centrifugal mendominasi di antara total fan dan blower dengan mengkonsumsi 90\% energi sektor [4]. Primary air fan dioperasikan secara terus menerus, dalam pengoperasiannya tidak selamanya performa yang dihasilkan fan itu konstan, karena adanya beberapa faktor yang menyebabkan perubahan performa fan sehingga terjadi fluktuasi pada performa fan dan jauh dari peforma desain awal [5]. Untuk meningkatkan kinerja fan, banyak penelitian telah dilakukan. Misalnya, fan blade bending sweep technology dan blade twisting technology adalah teknik yang paling umum digunakan [6]. N. Madhwesh pada penelitiannya mengatakan adaptasi geometris seperti pemangkasan impeller, side clearance, splitters, dan blade cutback telah dipelajari secara ekstensif oleh penulis dan itu diamati bahwa tindakan seperti itu umumnya mengarah pada perbaikan dalam kinerja centrifugal fan karena ditambah kenaikan tekanan statis pada fan [7]. S.Zhou pada penelitiannya dengan judul "Research On Blade Design Method Of Multi-Blade Centrifugal Fan For Building Efficient Ventilation Based On Hicks-Henne Function" bagian inti dari multi-blade centrifugal fan, impeler terutama terdiri dari blades, shroud dan back plate [8]. Fakta telah membuktikan bahwa optimalisasi struktur blade dapat sangat meningkatkan kinerja aerodinamis fan. Perubahan geometri volute parameter seperti jarak radial antara impeller dan volute memiliki pengaruh yang signifikan pada kinerja blower centrifugal [9]. Indra Djodikusumo pada penelitiannya dengan judul “Desain dan Pemodelan Sudu Primary Air Fan untuk Pembangkit Listrik Tenaga Uap ( PLTU)" dijelaskan bahwa aliran pada PA fan sangat rumit dan detail [10]. Tidak ada model matematika yang dapat diselesaikan secara analitis untuk menggambarkan kondisi aliran pada PA Fan. Salah satu solusinya adalah kajian eksperimen, namun ini membutuhkan usaha dan biaya yang sangat besar. Solusi lain yang lebih layak sebelum dilakukan kajian eksperimen adalah simulasi komputer menggunakan 


\section{Lohdy Diana, Studi Numerik Centrifugal Fan Tipe Impeller Backward dengan...}

software yang dikenal sebagai computational fluid dynamics (CFD) yang mengacu pada hasil kajian ekperimen. Pada pendekatan komputasi digunakan software komputasi fluida karena sudah teruji dalam skala industri dengan tingkat akurasi tinggi [11]. L. Umamaheswararao pada penilitiannya dengan judul "Performance Optimization of Centrifugal Fan with Ducts through CFD Simulation of Impeller Design" menggunakan CFD untuk meningkatkan hasil tekanan statik yang dihasilkan saat masuknya impeller dan efisiensi statis [12]. Optimasi CFD akan juga membantu meningkatkan pola aliran melalui sistem centrifugal fan. Pada tahap simulasi dilakukan analisis CFD dilakukan pada desain impeller yang berbeda di kecepatan yang berbeda dengan mengubah bentuk dan sebagai serta jumlah blade. Itu perbandingan semua parameter di outlet fan ditampilkan dalam bentuk grafik representasi.

Tujuan penelitian ini adalah untuk mengetahui pengaruh variasi putaran fan terhadap karakteristik aliran fluida berupa distribusi tekanan total, tekanan dinamis, tekanan statis, distribusi kecepatan, dan efisiensi optimal pada centrifugal fan khususnya pada bagian volute [13]. Volute merupakan bagian sisi atas sebelum saluran luaran fluida pada centrifugal fan. Penelitian ini dilakukan secara numerik dengan mensimulasikan centrifugal fan tipe impeller backward dalam model dua dimensi menggunakan software komputasi fluida dengan metode multiple reference frames dengan variasi putaran.

\section{METODE PENELITIAN}

Penelitian dilakukan secara simulasi, langkah awal yang dilakukan adalah menggambar model sesuai ukuran kemudian menentukan kondisi batas centrifugal fan. Ukuran dan kondisi batas ditunjukkan seperti pada Gambar 1. Spesifikasi centrifugal fan yang digunakan pada ditampilkan pada Tabel 1 [14]. Untuk input parameter simulasi diperlukan data operasi centrifugal fan dan data parameter simulasi ditampilkan pada Tabel $2[15-18]$.

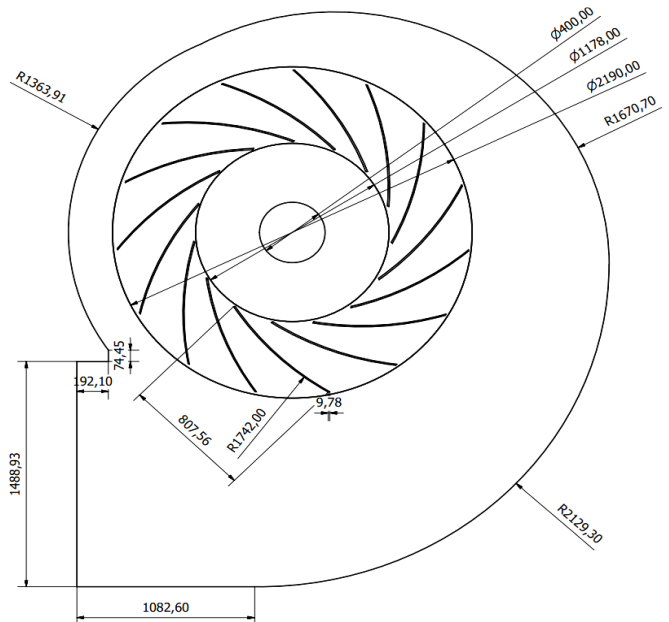

(a)

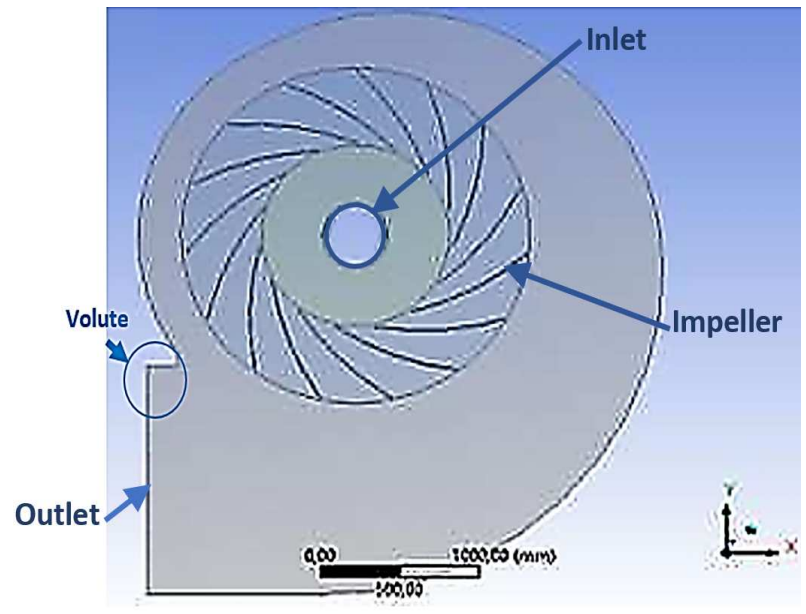

(b)

Gambar 1. Centrifugal fan (a) ukuran, (b) kondisi batas 
JMEMME, Vol 5 (01) (2021): 168-178

Tabel 1. Spesifikasi centrifugal fan

\begin{tabular}{|c|c|c|c|}
\hline No. & Name & Content & Unit \\
\hline 1 & Type & $\begin{array}{c}\text { Draft double- support } \\
\text { centrifugal }\end{array}$ & \\
\hline 2 & Flow rate & 122.21 & $\mathrm{~m}^{3} / \mathrm{s}$ \\
\hline 3 & $\begin{array}{l}\text { PAF outlet } \\
\text { pressure }\end{array}$ & 16800 & $\mathrm{~Pa}$ \\
\hline 4 & Voltage of motor & 6 & KV \\
\hline 5 & Power & 2000 & KW \\
\hline 6 & Speed of motor & 1490 & $\mathrm{r} / \mathrm{min}$ \\
\hline
\end{tabular}

Tabel 2. Data Parameter centrifugal fan

\begin{tabular}{ccccc}
\hline Fan type & Centrifugal & Use & PA Fan & Medium air \\
\hline Volume flow & $\mathrm{m}^{3} / \mathrm{a}$ & 91.17 & 67.038 & 66.628 \\
& & 2 & & \\
Atmosphere & $\mathrm{Pa}$ & 10132 & & \\
& & 5 & & \\
Density in NTP & $\mathrm{Kg} / \mathrm{m}^{3}$ & 16800 & $\mathrm{~Pa}$ & \\
Temperature & $\mathrm{C}$ & 30 & 30 & 30 \\
Density & $\mathrm{Kg} / \mathrm{m}^{3}$ & 1.162 & 1.1726 & 1.1726 \\
& & 6 & & \\
Inlet static head & $\mathrm{Pa}$ & & & \\
Inlet total & $\mathrm{Pa}$ & -625 & -324 & -318 \\
pressure & & & & \\
\hline
\end{tabular}

Bentuk mesh yang dihasilkan pada model 2D centrifugal fan dibuat menggunakan software Mesh. Bentuk mesh dibuat rapat dan kecil-kecil pada wilayah sudu impeller. Berikut hasil mesh pada proyek akhir ini dengan 100087 nodes dan 97358 elements dengan hasil skewness yaitu 0,424 dan orthogonal quality yaitu 0,29. Menurut ansys guide hasil mesh quality dapat digolongkan baik sesuai Tabel 3 dan Tabel 4.

Tabel 3. Skewness mesh metrics

\begin{tabular}{cccccc}
\hline Excellent & $\begin{array}{c}\text { Very } \\
\text { Good }\end{array}$ & Good & Acceptable & Bad & Uncceptable \\
\hline $0-0.25$ & $0.25-0.50$ & $0.50-0.80$ & $0.80-0.94$ & $0.95-0.97$ & $0.98-1.00$
\end{tabular}

Tabel 4. Orthogonal Quality mesh metrics

\begin{tabular}{cccccc}
\hline Uncceptable & Bad & Acceptable & Good & Very good & Excellent \\
\hline $0-0.001$ & $0.001-0.14$ & $0.15-0.20$ & $0.20-0.69$ & $0.70-0.95$ & $0.95-1.00$
\end{tabular}

Metode grid independency diperlukan untuk menghasilkan data yang lebih akurat dengan bentuk mesh yang optimal. Dengan menggunakan data tekanan total untuk melakukan iterasi jumlah grid. Bentuk mesh ditunjukkan pada Gambar 2b. Solver yang digunakan adalah pressure based untuk asumsi aliran incompressible dan pengoperasian simulasi konvergen pada keadaan aliran steady. Menggunakan material udara dengan viskositas 1,225. Simulasi dijalankan menggunakan coupled solver untuk pressure-velocity 


\section{Lohdy Diana, Studi Numerik Centrifugal Fan Tipe Impeller Backward dengan...}

coupling dengan second order upwind scheme dipilih untuk menyelesaikan persamaan umum yang dipakai. Initialisasi dilakukan dengan metode hybrid initialization lalu iterasi dilakukan kurang lebih 10000 iterasi. Hasil grid independence ditunjukkan pada Tabel 5.

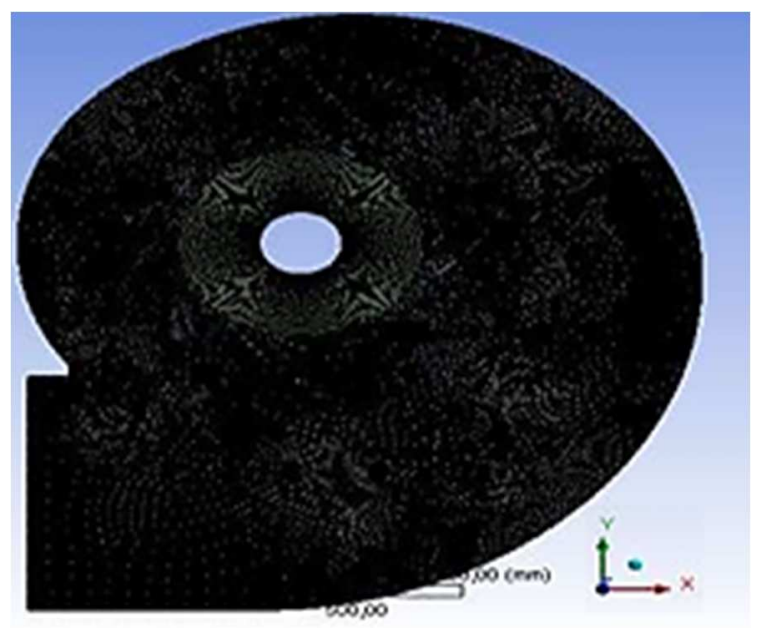

(a)

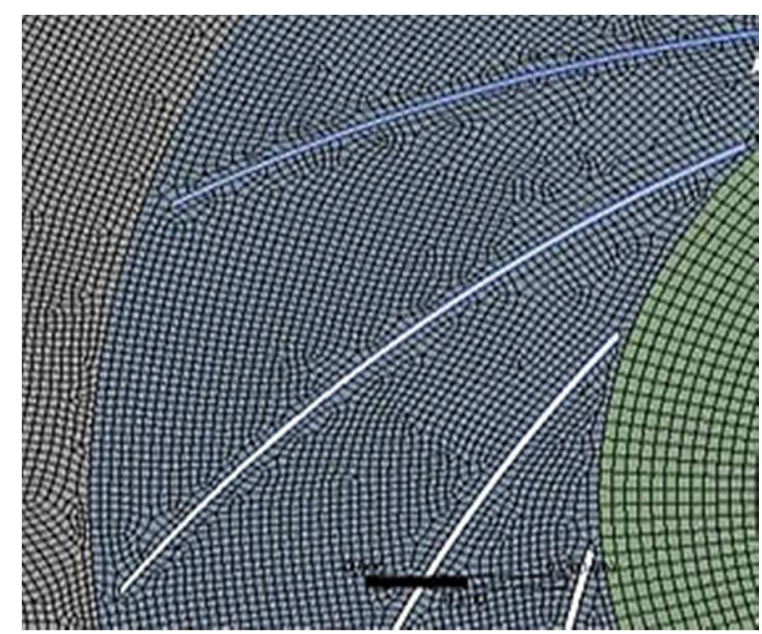

(b)

Gambar 2. Hasil meshing geometri 2D (a) tampak keseluruhan (b) tampak detail

Tabel 5. Grid independence

\begin{tabular}{ccccccc}
\hline \multicolumn{1}{c}{ Mesh } & \multicolumn{3}{c}{ Statistics } & & Total & $\begin{array}{c}\text { Tekanan total } \\
\text { Outlet (Pa) }\end{array}$ \\
\hline \multirow{2}{*}{ A } & Nodes & 64418 & 29624 & 6045 & 100087 & 17564,9 \\
& Elements & 63544 & 27964 & 5850 & 97358 & \\
\multirow{2}{*}{ B } & Nodes & 78466 & 37725 & 7665 & 123856 & \multirow{2}{*}{18241,8} \\
& Elements & 77497 & 35879 & 7446 & 120822 & \\
\hline
\end{tabular}

Tabel 6. Validasi

\begin{tabular}{lccc}
\hline RPM & $\begin{array}{l}\text { Tekanan total } \\
\text { Outlet(Aktual)Pa }\end{array}$ & $\begin{array}{c}\text { Tekanan total } \\
\text { Outlet (Simulasi)Pa }\end{array}$ & Error \% \\
\hline 1468 & 16800 & 17564,9 & 4,5529 \\
\hline
\end{tabular}

Validasi merupakan terminologi untuk menunjukkan tingkat kebenaran dari simulasi yang dilakukan. Untuk menentukan tingkat kevalidan, dapat dilakukan dengan beberapa metode yaitu kasus yang ditinjau serta dengan cara membandingkan dengan sebuah standard yang telah ada dengan referensi yang jelas. Hasil validasi ditunjukkan pada Tabel 6. Analisa hasil simulasi dilakukan setelah melakukan tahap processing. Data yang diambil dari hasil simulasi berupa data kualitatif visualisasi distribusi tekanan dan distribusi kecepatan sedangkan data kuantitatif berupa kecepatan aliran dalam bentuk grafik outlet. Sebelum memasuki tahap analisa, dilakukan validasi perbandingan tekanan total pada sisi outlet centrifugal fan dengan tekanan total yang terukur di centrifugal fan aktual sesuai tabel. 
Berdasarkna Tabel 4 diketahui error yang hasilkan tidak mencapai 10\% sehingga simulasi centrifugal fan dapat dikatakan mendekati centrifugal fan aktual.

Data yang disajikan yaitu kontur distribusi tekanan total, kontur distribusi kecepatan, grafik kecepatan fluida pada outlet, grafik efisiensi terhadap putaran centrifugal fan, dan grafik tekanan. Tekanan disini dibagi menjadi 3 yaitu tekanan total, tekanan dinamis dan tekanan statis sesuai persamaan bernoulli yaitu

$$
\boldsymbol{P}_{o}=\mathrm{P}+\frac{1}{2} \rho V^{2}
$$

\section{HASIL DAN PEMBAHASAN}

Gambar 3 dan Gambar 4 menunjukkan hasil simulasi berupa distribusi tekanan dan distribusi kecepatan terhadap variasi putaran.

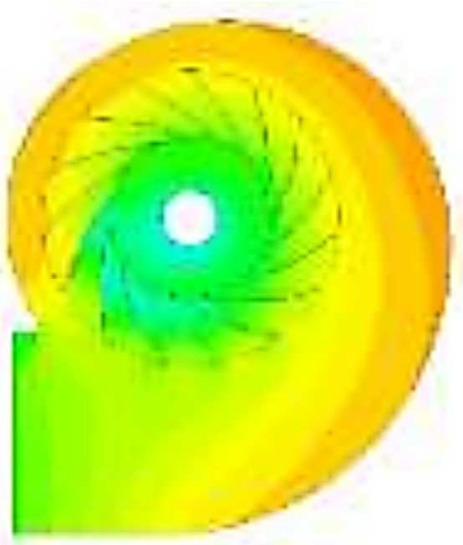

(a)

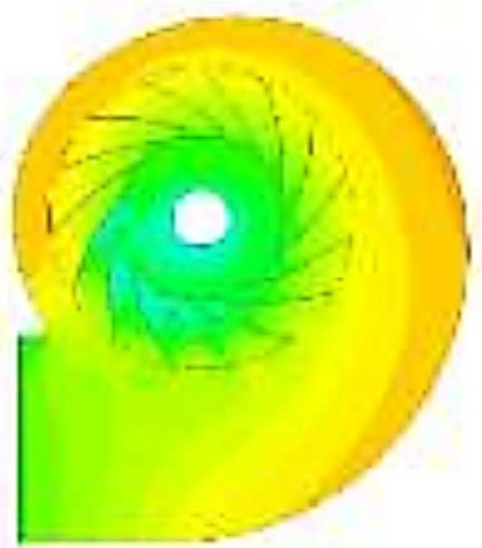

(b)

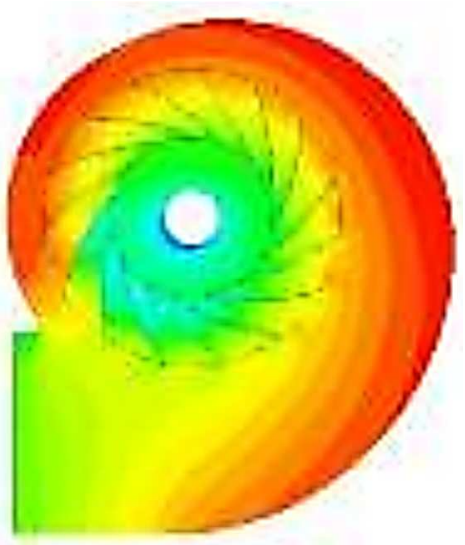

(c)

Gambar 3. Distribusi tekanan total pada putaran: (a) 1194 rpm, (b) 1223 rpm, dan (c) 1468 rpm

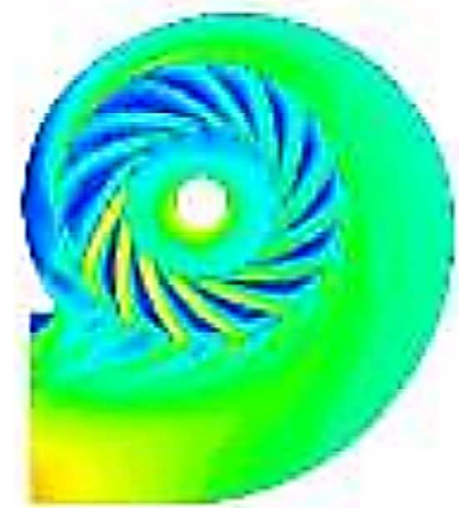

(a)

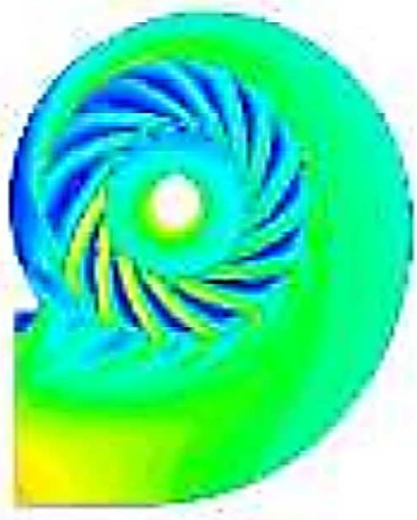

(b)

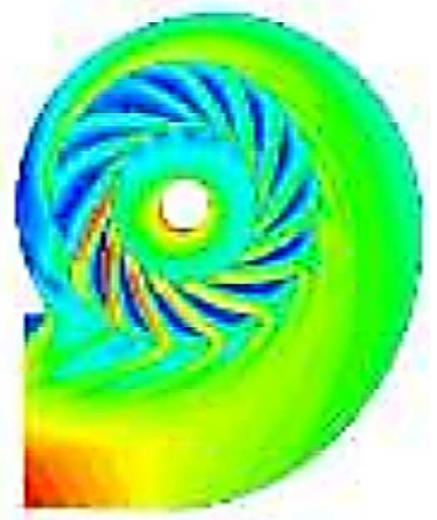

(c)

Gambar 4. Distribusi kecepatan pada putaran: (a) 1194 rpm, (b) 1223 rpm, dan (c) 1468 rpm

Berdasarkan distribusi tekanan dan distribusi kecepatan seperti pada Gambar 4 dan terjadi fenomena volute yaitu mengubah energi kecepatan menjadi energi tekanan. Ketika fluida yang masuk suction atau inlet diputar oleh impeller maka kecepatan bertambah sehingga sisi suction atau inlet terjadi kevakuman dan impeller yang berputar akan 
meneruskan dan memberikan gaya putar centrifugal kepada fluida sehingga fluida bergerak keluar dengan tekanan tinggi sesuai dengan luas penampang volute yang semakin lama semakin membesar. Sesuai hukum kontinuitas, jika semakin besar luas penampang suatu ruang maka kecepatan akan berkurang sedangkan tekanannya bertambah, begitu juga sebaliknya dapat dilihat sisi terluar volute terlihat semakin besar tekanan semakin kecil kecepatan.

Dilihat di bagian inlet atau suction semakin besar putaran impeller semakin kecil nilai tekanannya atau dalam kondisi vakum yang meningkat sedangkan di bagian volute tepatnya di outlet atau discharge semakin besar putaran impeller semakin besar tekanan. Untuk mengamati pengaruh putaran centrifugal fan terhadap tekanan dalam simulasi ini di plot dimana sumbu X adalah sepanjang outlet atau discharge dalam satuan meter dan $\mathrm{Y}$ adalah besar tekanan dalam satuan pascal, tekanan disini dibagi menjadi 3 yaitu tekanan total, tekanan dinamis dan tekanan statis sesuai persamaan bernoulli (1).

Gambar 5 menunjukkan grafik tekanan total pada outlet dan gambar 6 menunjukkan grafik tekanan dinamis pada outlet. Berdasarkan Gambar 7 dapat dilihat nilai tekanan terhadap sisi outlet atau discharger yang cenderung sama, disimulasi ini putaran antara rpm 1194 dan rpm 1223 terjadi selisih yang tidak terlalu signifikan dibandingkan dengan rpm 1468 sehinggga dapat dibuat kesimpulan besar tekanan total dan dinamis mengalami kenaikan seiring bertambahnya putaran fan.

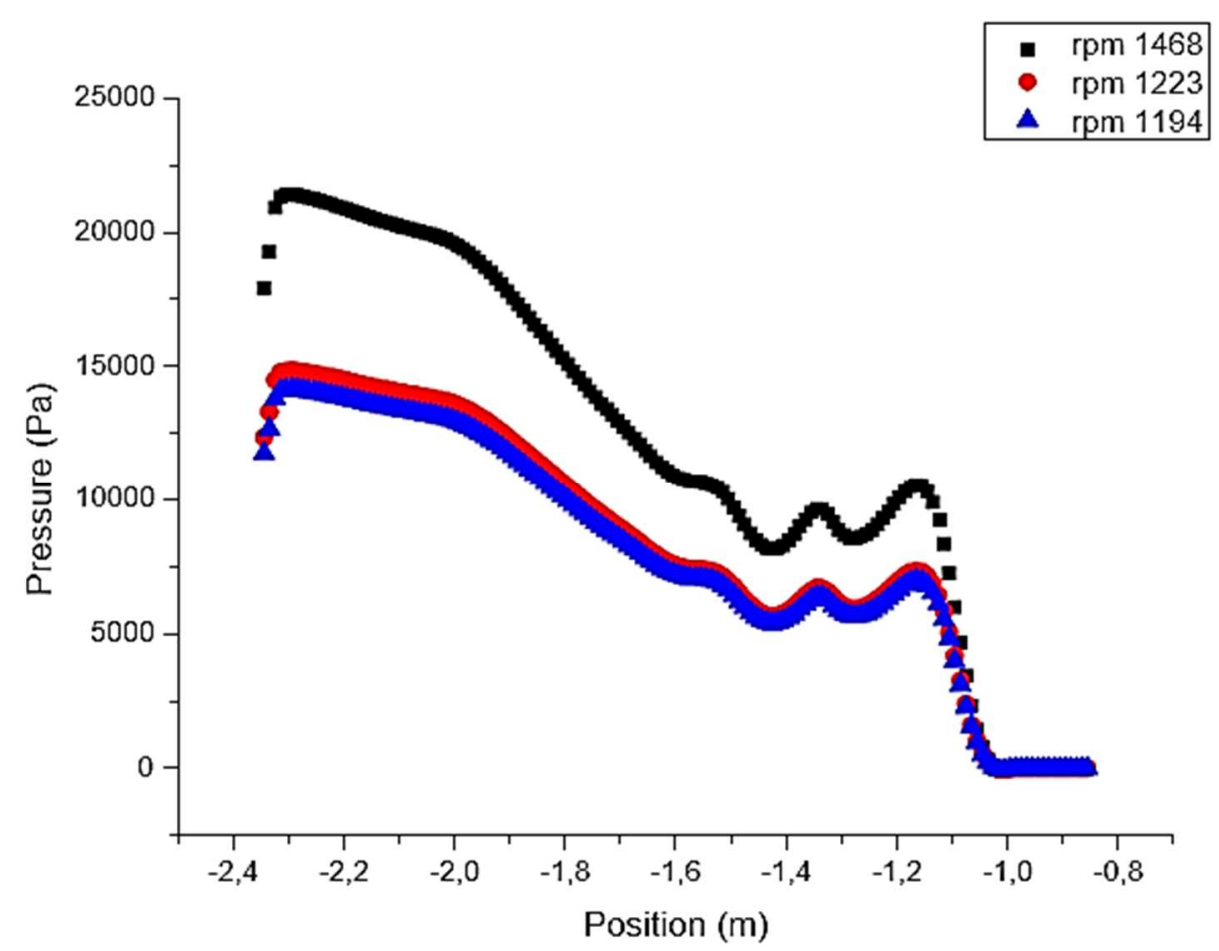

Gambar 5. Grafik tekanan total pada outlet 


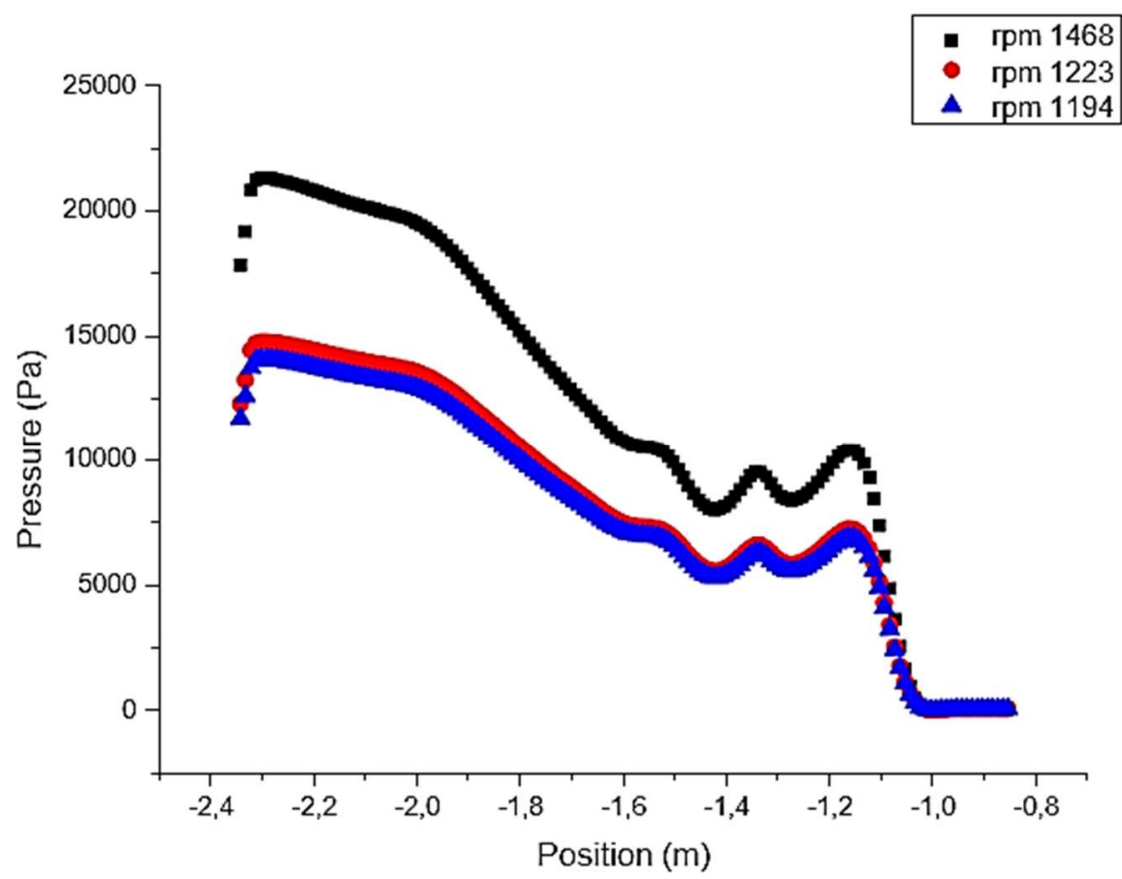

Gambar 6. Grafik tekanan dinamis pada outlet

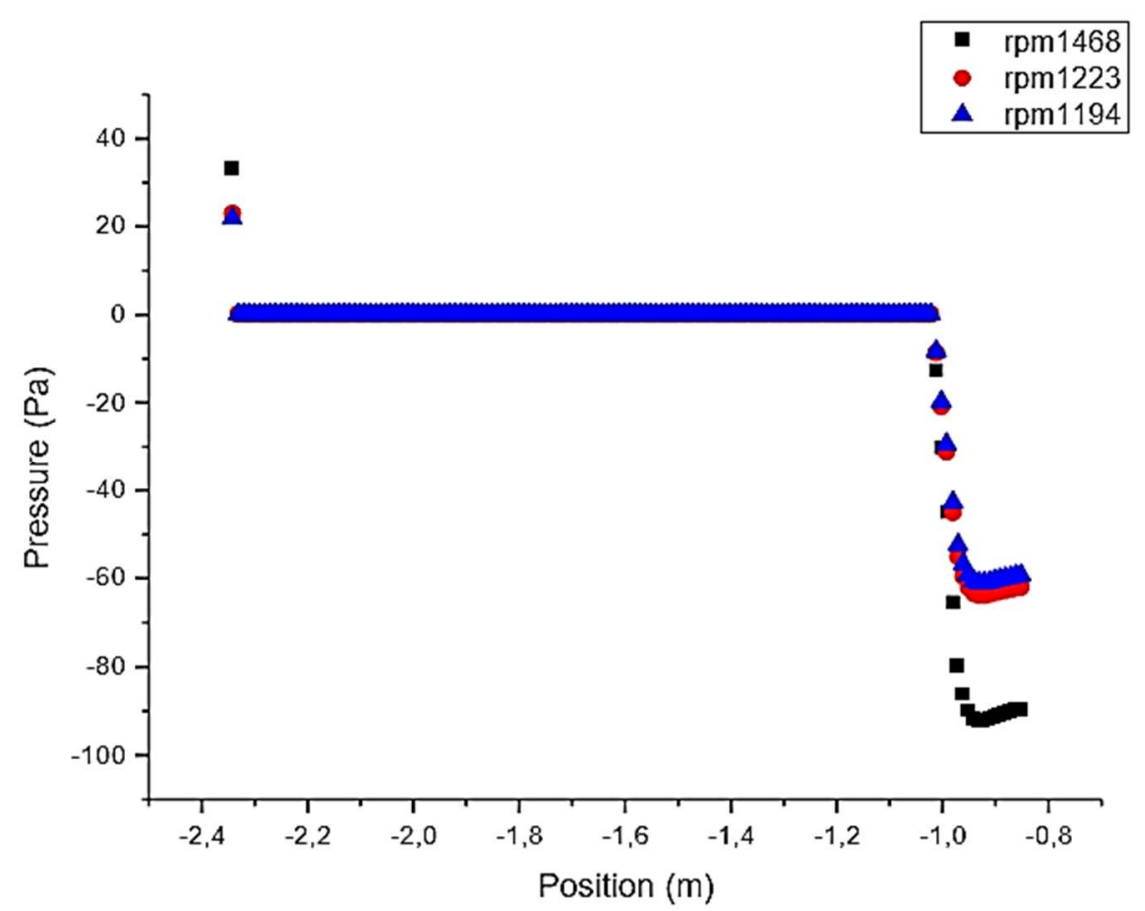

Gambar 7. Grafik tekanan statis pada outlet

Berdasarkan Gambar 8 yang merupakan grafik distribusi kecepatan pada outlet dapat dilihat mempunyai karakteristik besar nilai kecepatan terhadap sisi outlet atau discharger yang cenderung sama, disimulasi ini putaran antara rpm 1194 dan rpm 1223 terjadi selisih yang tidak terlalu signifikan dibandingkan dengan rpm 1468 sehinggga dapat dibuat 


\section{Lohdy Diana, Studi Numerik Centrifugal Fan Tipe Impeller Backward dengan...}

kesimpulan kecepatan mengalami kenaikan seiring bertambahnya putaran fan. Dilihat di outlet posisi -0,8531m sampai -1,01301 hasil kecepatan bernilai mendekati nilai $0 \mathrm{~m} / \mathrm{s}^{2}$ hal itu menunjukkan bahwa kecepatan minimum terjadi di area tersebut hal itu terjadi karena ketika impeller mengeluarkan gaya centrifugal untuk meneruskan aliran fluida, aliran mengalir ke daerah radius volute tongue terjadi tabrakan dan itu mengakibatkan kecepatan di daerah tersebut mengalami penurununan kecepatan hingga $V=0$, yang ditunjukkan pada Gambar 8.

Fan efficiency merupakan rasio fan output power terhadap fan input power. Ini juga dapat disebut efisiensi total. Berdasarkan hasil simulasi centrifugal fan di variasi putaran centrifugal fan pada penelitian ini menggunakan sebanyak 5 variasi rpm yang berbeda dan dilakukan perhitungan didapatkan nilai efisiensi seperti pada Gambar 9 yang merupakan grafik efisiensi terhadap putaran centrifugal fan pada putaran $1194 \mathrm{rpm}$ memiliki nilai efisiensi 61,73\% dan putaran 1223 rpm memiliki efisiensi terbesar dengan nilai 61,74\%, dan putaran $1468 \mathrm{rpm}$ memiliki efisiensi terkecil dengan nilai 61,58\%. Dari hasil tersebut grafik efisiensi terhadap rpm membentuk garis parabola dimana semakin besar nilai putaran fan belum tentu nilai efisiensi juga akan semakin besar itu terverifikasi dengan data spesifikasi aktual lapangan dengan nilai range putaran minimum 1194 rpm sampai maksimum 1468 rpm.

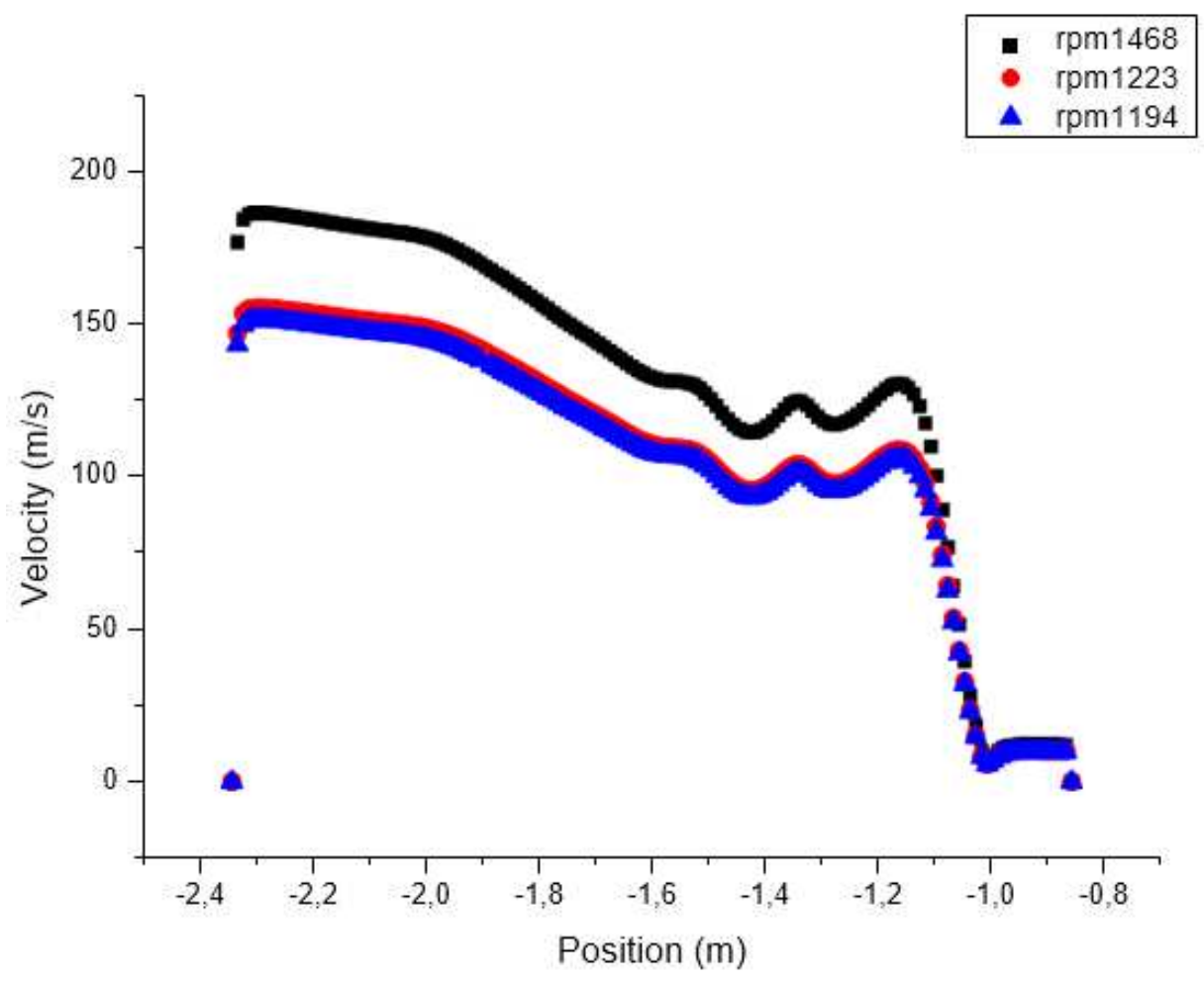

Gambar 8. Grafik kecepatan fluida pada outlet 


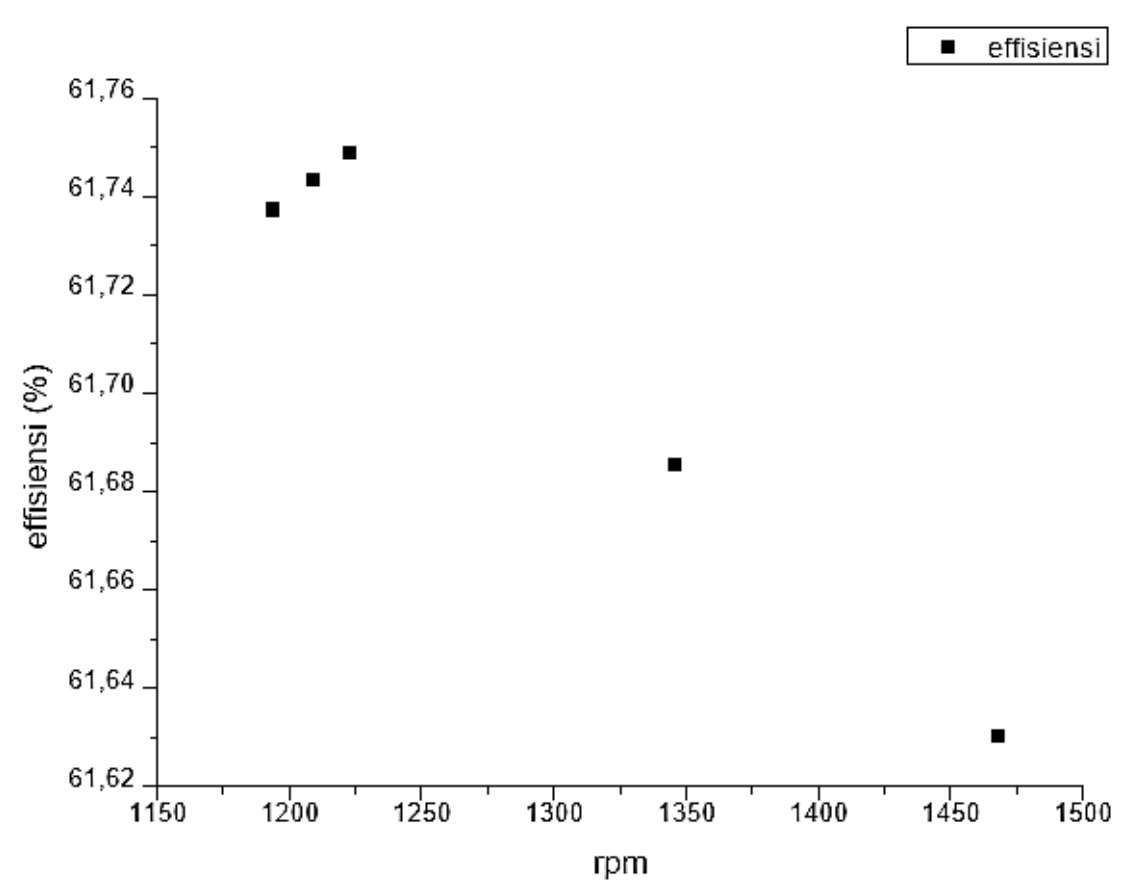

Gambar 9. Efisiensi terhadap putaran centrifugal fan

\section{KESIMPULAN}

Berdasarkan hasil analisis mengenai pengaruh variasi putaran centrifugal fan terhadap karakteristik aliran fluida menggunakan metode komputasi dinamika fluida dapat disimpulkan bahwa distribusi tekanan dan distribusi kecepatan semakin besar luasan di volute, semakin besar nilai pressure total. Pada distribusi kecepatan outlet posisi $-0,8531 \mathrm{~m}$ sampai -1,01301 hasil kecepatan fluida bernilai mendekati nilai $0 \mathrm{~m} / \mathrm{s} 2$ hal tersebut menunjukkan bahwa kecepatan minimum di area tersebut akibat profil volute yaitu radius volute tongue terjadi tabrakan aliran dan itu mengakibatkan kecepatan di daerah tersebut mengalami penurununan kecepatan hingga $V=0$. Pada variasi putaran centrifugal fan membentuk garis parabola dimana semakin besar nilai putaran fan belum tentu nilai effisiensi juga akan semakin besar itu terverifikasi dengan data spesifikasi aktual lapangan dengan nilai range putaran minimum 1194 rpm sampai maksimum 1468 rpm.

\section{REFERENSI}

[1] S. R. Patil, S. T. Chavan, N. S. Jadhav, and S. S. Vadgeri, "Effect of Volute Tongue Clearance Variation on Performance of Centrifugal Blower by Numerical and Experimental Analysis," Mater. Today Proc., vol. 5, no. 2, pp. 3883-3894, 2018.

[2] C. Stadium, P. M. Palem, and A. Vinutha, "The Effect of Impeller Blade Design on Centrifugal Blower - CFD Approach,” Int. J. Innov. Technol. Res., vol. 5, no. 5, pp. 6915-6918, 2017.

[3] ASME (American Society of Mechanical Engineer) PTC 11, vol. 2008.

[4] B. D. Baloni, S. A. Channiwala, and S. N. R. Harsha, "Design, Development and Analysis of Centrifugal Blower,” J. Inst. Eng. Ser. C, vol. 99, no. 3, pp. 277-284, 2018.

[5] G. Chen, W. Xu, J. Zhao, and H. Zhang, "Energy-Saving Performance Of Flap-Adjustment-Based Centrifugal Fan," J. Energies MDPI, vol. 11, no. 1, pp. 1-14, 2018.

[6] X. Zhang, Y. Zhang, and C. Lu, "Flow And Noise Characteristics Of Centrifugal Fan In Low Pressure Environment," J. Process. MDPI, vol. 8, no. 8, 2020. 


\section{Lohdy Diana, Studi Numerik Centrifugal Fan Tipe Impeller Backward dengan...}

[7] N. Madhwesh, K. Vasudeva Karanth, and N. Yagnesh Sharma, "Effect Of Innovative Circular Shroud Fences On A Centrifugal Fan For Augmented Performance - A Numerical Analysis,” J. Mech. Sci. Technol., vol. 32, no. 1, pp. 185-197, 2018.

[8] S. Zhou, H. Zhou, K. Yang, H. Dong, and Z. Gao, "Research On Blade Design Method Of Multi-Blade Centrifugal Fan For Building Efficient Ventilation Based On Hicks-Henne Function,” Sustain. Energy Technol. Assessments, vol. 43, no. December 2020.

[9] V. Chaudhari, V. Parmar, and M. J. Zinzuvadia, "Parametric Study and Geometrical Optimization of Centrifugal Blower," Kalpa Publ. Eng., vol. 1, pp. 96-88, 2018.

[10] I. Djodikusumo, I. N. Diasta, I. S. Awaludin, and A. Iriawan, "Desain dan Pemodelan Sudu Primary Air Fan untuk Pembangkit Listrik Tenaga Uap ( PLTU )," Proceeding Semin. Nas. Tah. Tek. Mesin XV, no. Snttm Xv, pp. 5-6, 2016.

[11] K. C. More, S. Dongre, and G. P. Deshmukh, "Experimental And Numerical Analysis Of Vibrations In Impeller Of Centrifugal Blower," SN Appl. Sci., vol. 2, no. 1, pp. 1-14, 2020.

[12] L. Umamaheswararao, M. Tech, V. Chandrasimha, and K. S. A. Al-Khobar, "Performance Optimization of Centrifugal Fan with Ducts through CFD Simulation of Impeller Design," Int. J. Mech. Eng., vol. 5, pp. 1-7, 2020.

[13] Y. Lun, L. Lin, H. He, X. Ye, Z. Zhu, and Y. Wei, "Effects Of Vortex Structure On Performance Characteristics Of A Multiblade Fan With Inclined Tongue," Proc. Inst. Mech. Eng. Part A J. Power Energy, vol. 233, no. 8, pp. 1007-1021, 2019.

[14] C. N. E. Engineering, Boiler Operation Manual Indonesia PT PJB UBJ O\&M PT PJB UBJ O\&M PLTU Tanjung Awar-Awar 2 x 350 MW. .

[15] ANSYS, ANSYS, Inc, Ansys Fluent User's Guide 14.5. 2012.

[16] A. J. Zulfikar, A. Sofyan and M. Y. Siahaan, "Numerical Simulation on The Onion Dryer Frame Capacity of $5 \mathrm{~kg} /$ hour," JMEMME (Journal of Mechanical Engineering Manufactures Materials and Energy), vol. 2, no. 2, p. 86-92, 2018.

[17] A. Sofyan, J. Glusevic, A.J. Zulfikar, B. Umroh, "Analisis Kekuatan Struktur Rangka Mesin Pengering Bawang Menggunakan Perangkat Lunak Ansys Apdl 15.0", JMEMME (Journal of Mechanical Engineering Manufactures Materials and Energy), vol. 3, no. 1, p. 20-28, 2019.

[18] A. J. Zulfikar and M. Y. R. Siahaan, "Analisis Signifikansi Roda Skateboard Berbahan Komposit Serbuk Batang Pisang Terhadap Perfoma Kecepatan Dengan Metode Anova," Jurnal Rekayasa Material, Manufaktur dan Energi, vol. 4, no. 2, pp. 83-90, 2021. 